\title{
Proposal of public policies regarding the participation of the population of Romania in sports activities
}

\author{
Badiu Alina \\ Master of European Administration. Public institutions and policies (Faculty of Law and \\ Administrative Sciences - "Ovidius" University of Constanta, Romania) \\ alinabadiu03@yahoo.com \\ Volume coordinators \\ Prof. univ. dr. habil. Mihaela Rus \\ "Ovidius" University of Constanta (Faculty of Law and Administrative Sciences) \\ psiholog_m@yahoo.com \\ Lect. univ. dr. Mihaela Sandu \\ "Ovidius" University of Constanta (Faculty of Psychology and Educational Sciences) \\ mihaela_naidin@yahoo.com \\ Asist. univ. dr. Tănase Tasențe \\ "Ovidius" University of Constanta (Faculty of Law and Administrative Sciences) \\ office@pluscommunication.eu
}

\begin{abstract}
This problem symbolizes the importance that sport has in a person's life. No one disputes the fact that the practice of sport has many benefits for human health. It is a worrying statistic, considering that the young generation is no longer willing to play sports, but judging from these statistics, there will be no investments in this branch. One of the most important desires of today's society consists in a healthy life that requires a healthy and adequate nutrition, but not least an active life. In Romania more than half of the population is facing the problem of obesity, also occupying the second place in Europe in the ranking of overweight, the most targeted being children. The general objective of the public policy proposal is to integrate the activities in the field of physical education into the curricular activities.
\end{abstract}

Keywords. public policy, sports activities, Romania 


\begin{tabular}{|c|c|}
\hline $\begin{array}{l}\text { The institution that } \\
\text { initiates public policy }\end{array}$ & Youth and Sports Ministry \\
\hline $\begin{array}{l}\text { The nature of the } \\
\text { problem }\end{array}$ & $\begin{array}{l}\text { This problem symbolizes the importance that sport has in a person's life. } \\
\text { No one disputes the fact that the practice of sport has many benefits for } \\
\text { human health. This is a worrying statistic (Appendix 1), given that the } \\
\text { young generation is no longer willing to play sports, but judging from } \\
\text { these statistics, there will be no investments in this branch. } \\
\text { One of the most important desires of today's society consists in a } \\
\text { healthy life that requires a healthy and adequate nutrition, but not least } \\
\text { an active life. } \\
\text { In Romania more than half of the population is facing the problem of } \\
\text { obesity, also occupying the second place in Europe in the ranking of } \\
\text { overweight, the most targeted being children. This is the fault of the } \\
\text { parents, who are also involved in this public policy proposal - in the } \\
\text { process of public consultation, because they are not an example for their } \\
\text { children, they do not encourage and educate them to have a sporting or } \\
\text { even more active spirit. The technological context is frequently } \\
\text { mentioned, as children are rather attracted to the digital environment } \\
\text { (tablets, phones, internet, etc.) and eliminate physical exercises from } \\
\text { their program. Today, a child hardly understands how important sport is } \\
\text { in human life, especially since his main activity, in his free time, is to } \\
\text { stand in front of the television, computer, tablet or mobile phone. } \\
\text { Virtual reality has completely captured him, so most of the time, he } \\
\text { refuses to have fun in the park with friends, on the playground or to } \\
\text { attend different events according to his age. }\end{array}$ \\
\hline Name of the policy & $\begin{array}{l}\text { Proposal of public policies regarding the participation of the population } \\
\text { of Romania in sports activities }\end{array}$ \\
\hline Purpose & $\begin{array}{l}\text { The purpose of this program in Romania is to promote sport in the life } \\
\text { of every person, regardless of age, to involve as many Romanian } \\
\text { citizens as possible in sporting activities. Sport can contribute to social } \\
\text { development, so by practicing a sport we can convey important social } \\
\text { values, such as self-discipline, solidarity, team spirit, tolerance and } \\
\text { sportsmanship. }\end{array}$ \\
\hline $\begin{array}{l}\text { General objective } \\
\text { Specific objectives }\end{array}$ & $\begin{array}{l}\text { General objective: to integrate physical education activities into } \\
\text { curricular activities. } \\
\text { Specific objectives: } \\
\text { 1. Mandatory introduction of physical education classes in elementary } \\
\text { schools and high schools; } \\
\text { 2. Better training of teachers; } \\
\text { 3. Higher funds for sports activities and its encouragement. } \\
\text { 4. Improvement of the institutions that carry out activities in the sports } \\
\text { field. } \\
\text { 5. Encourage citizens to play a sport and have a more active life. } \\
\text { 6. Accessing European funds. Financing of some funds from the state } \\
\text { for sports activities in order to encourage the citizens of Romania to } \\
\text { participate in them. } \\
\text { 7. Introducing a set of activities in schools: } \\
\text { - motion games with a role in the physical and mental development of }\end{array}$ \\
\hline
\end{tabular}




\begin{tabular}{|c|c|c|}
\hline & \multicolumn{2}{|c|}{$\begin{array}{l}\text { children: "stone bridge", "ball pole", etc. } \\
\text { - bilateral sports games that involve the development of team spirit, } \\
\text { competitiveness, the sense of sacrifice, the desire to win and self- } \\
\text { promotion, the presence of spirit: football, basketball, handball, } \\
\text { volleyball; } \\
\text { - creation of team-building groups in order to increase the degree of } \\
\text { individual participation and to build the capacity to work in a team; }\end{array}$} \\
\hline Beneficiaries & \multicolumn{2}{|c|}{$\begin{array}{l}\text { Direct: it concerns all the citizens of Romania. } \\
\text { Indirect: owners of sports clubs, fitness rooms, aerobics rooms, etc. }\end{array}$} \\
\hline $\begin{array}{l}\text { Solution alternatives } \\
\text { no. } 1\end{array}$ & $\begin{array}{l}\text { The state to finance sports } \\
\text { competitions with more money, as } \\
\text { well as certain projects that } \\
\text { involve promoting a sport and a } \\
\text { healthy life. } \\
\text { Benefits: } \\
\text { The allocation of bigger funds also } \\
\text { means greater interest, both for the } \\
\text { citizens who will be informed } \\
\text { about the importance of sport, and } \\
\text { for the institutions that will carry } \\
\text { out as many projects as possible. } \\
\text { Risks: } \\
\text { Lack of necessary funds. } \\
\text { Disinterest by people who are not } \\
\text { attracted to sports. }\end{array}$ & $\begin{array}{l}\text { Impact } \\
\text { Important would be the } \\
\text { participation of several citizens, } \\
\text { especially the participation of } \\
\text { students to promote sport and a } \\
\text { healthier life, because today's } \\
\text { students are tomorrow's parents. } \\
\text { By this method of educating the } \\
\text { ascetic the future generations will } \\
\text { have from whom they learn. }\end{array}$ \\
\hline $\begin{array}{l}\text { Solution alternatives } \\
\text { no. } 2\end{array}$ & $\begin{array}{l}\text { More detailed information of the } \\
\text { population regarding sports and } \\
\text { how important it is by means such } \\
\text { as: TV shows, mass-media, } \\
\text { socialization sites, organization of } \\
\text { sports hours in public spaces by } \\
\text { the Ministry of Health and the } \\
\text { Ministry of Education. } \\
\text { Benefits: } \\
\text { - Familiarization with a healthier } \\
\text { and more balanced lifestyle } \\
\text {-responsibility of people who are } \\
\text { interested in playing sports } \\
\text { - increasing the number of people } \\
\text { in the practice of a sport } \\
\text { Risks: } \\
\text { - disinterest on the part of citizens } \\
\text { to get involved in sports activities } \\
\text { - lack of funds }\end{array}$ & $\begin{array}{l}\text { Impact } \\
\text { As a direct impact would be the } \\
\text { interest of the people in the } \\
\text { practice of a sport for a healthier } \\
\text { life, a fact to prevent the } \\
\text { appearance of certain diseases and } \\
\text { obesity. }\end{array}$ \\
\hline
\end{tabular}




\begin{tabular}{|c|c|}
\hline $\begin{array}{l}\text { Solution alternatives } \\
\text { no. } 3\end{array}$ & $\begin{array}{l}\text { Lower prices for fitness rooms } \\
\text { subscriptions. } \\
\text { Benefits: } \\
\text { With lower prices people would be } \\
\text { more tempted to make a } \\
\text { subscription. } \\
\text { Owners of an aerobics / fitness } \\
\text { room will be more interested in } \\
\text { lowering the price to attract } \\
\text { customers. } \\
\text { Risks: } \\
\text { The state does not have the power } \\
\text { to support this reduction of the } \\
\text { subscription. }\end{array}$ \\
\hline $\begin{array}{l}\text { The consultation } \\
\text { process }\end{array}$ & $\begin{array}{l}\text { In order to formulate the public policy and to identify the key points } \\
\text { for defining it, meetings were held with both qualified personnel } \\
\text { practicing sports and with other people passionate about this field. } \\
\text { They generated the information needed to formulate concrete } \\
\text { suggestions and recommendations in order to make a public policy } \\
\text { proposal, which would be a real solution. } \\
\text { Thus, the parties consulted were: } \\
\text { - Members of the Ministry of Youth and Sport of Romania. } \\
\text { - Representatives of students by age groups; } \\
\text { - Parents, teachers, psychologists, doctors. }\end{array}$ \\
\hline $\begin{array}{l}\text { Recommended } \\
\text { solution }\end{array}$ & $\begin{array}{l}\text { Following the evaluation of the three proposed variants, Variant } 2 \text { : } \\
\text { "More detailed information of the population regarding the sport and } \\
\text { how important it is by means such as: TV shows, mass-media, } \\
\text { socializing sites, organizing some hours of sports in public spaces by } \\
\text { the Ministry of Health and the Ministry of Education "represents the } \\
\text { most important step in determining the population to play sports, } \\
\text { providing as much information as possible on this field, and therefore } \\
\text { variant 3, which refers to it, can be implemented when reducing the } \\
\text { prices for fitness room subscriptions, reductions that will be financed } \\
\text { from the State Budget. }\end{array}$ \\
\hline
\end{tabular}




\section{Appendix 1}

The echo of this activity among the population of our country is reflected in the fact that in recent years, $60 \%$ of the population of Romania does not practice any form of sporting activity.

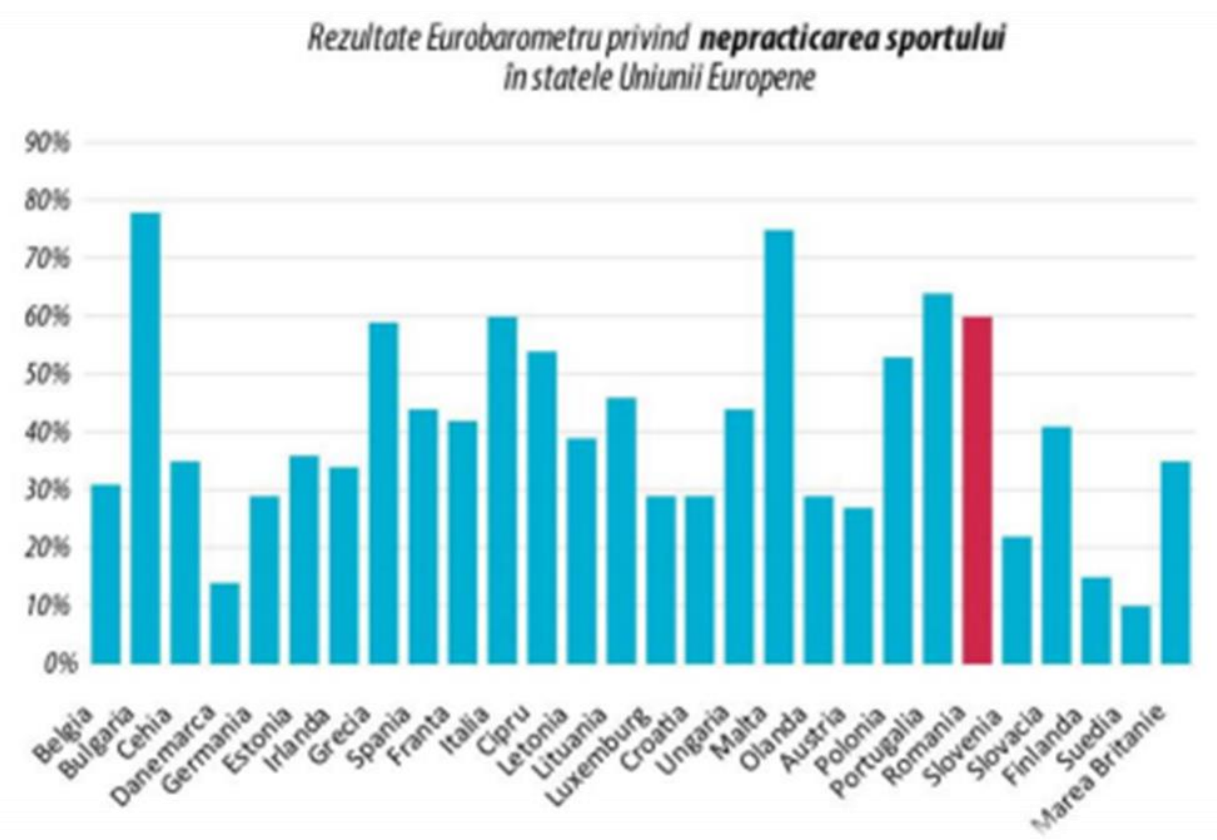

Figure 1 - Eurobarometer results on non-sports practice in the European Union states

The same source also highlights the percentages of non-sports, by gender and age.

\section{Studiu comparativ România UE privind nepracticarea sportuluide către populația masculină în raport cu vârsta}

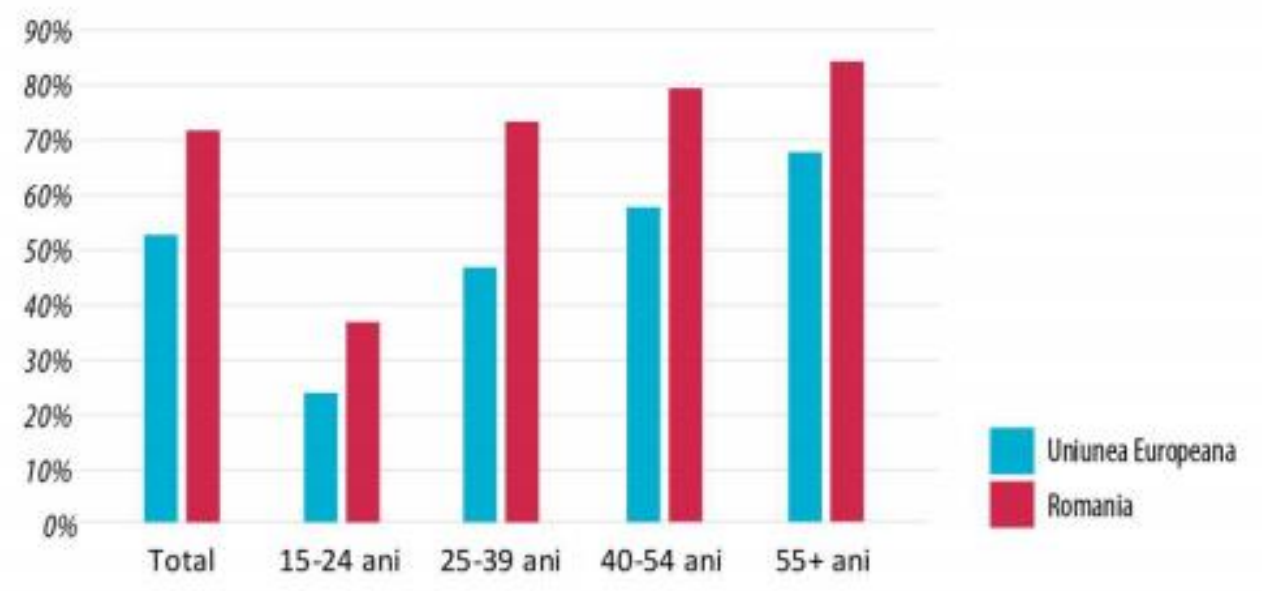

Figure 2 - Comparative study Romania - EU regarding the non-practice of sport by the male population in relation to the age 
Studiu comparativ România UE privind nepracticarea sportuluide către populațiafeminină în raport cu vârsta

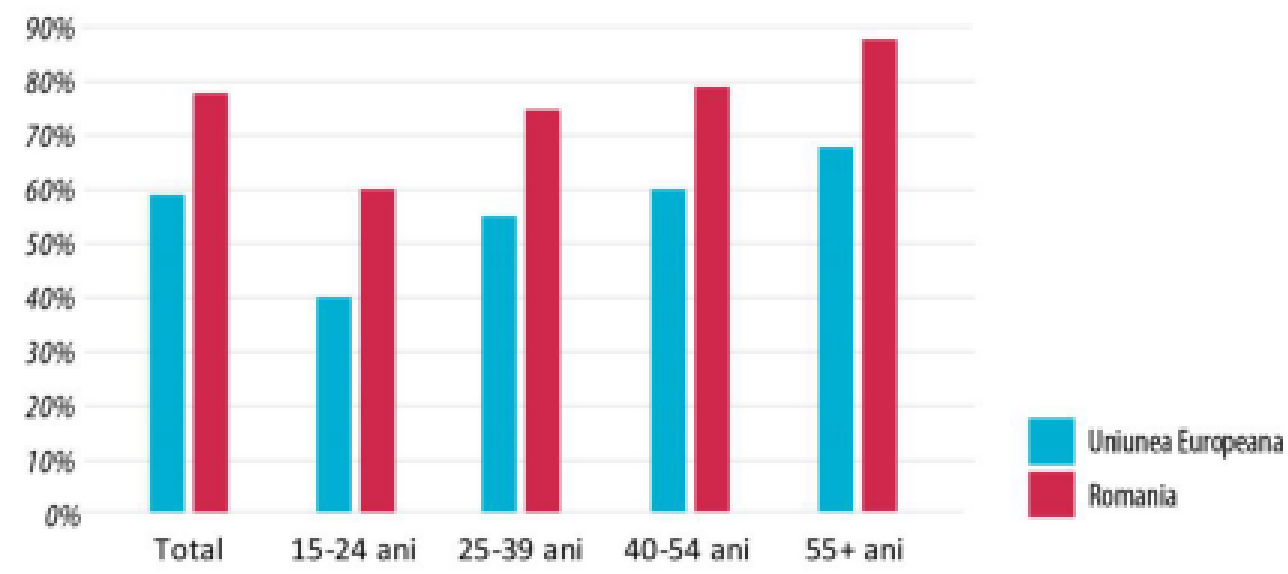

Figure 3 - Comparative study Romania - EU on the non-practice of sport by the female population in relation to the age 